Pobrane z czasopisma Annales H - Oeconomia http://oeconomia.annales.umcs.pl Data: 26/04/2023 16:33:49

DOI:10.17951/h.2018.52.1.141

\begin{tabular}{lcl}
\hline \multicolumn{1}{c}{ A N N A L E S } \\
UNIVERSITATIS MARIAE CURIE-SKŁODOWSKA \\
LUBLIN - POLONIA \\
VOL. LII, 1 & SECTIO H \\
\hline
\end{tabular}

Poznań University of Economics and Business. Faculty of Economics

PAWEŁ MARSZAŁEK

pawel.marszalek@ue.poznan.pl

\title{
Non-commercial Financial Intermediaries as an Alternative for Commercial Banks in the Post-crisis Economy
}

Niekomercyjne instytucje pośrednictwa finansowego jako alternatywa dla banków komerycjnych w gospodarce po kryzysie finansowym

Keywords: financial intermediation; credit unions; social lending; disintermediation

Słowa kluczowe: pośrednictwo finansowe; unie kredytowe; social lending; dezintermediacja

JEL Code: E42; E44; G21

\section{Introduction}

In the age of financialization, i.e. since the 1970s, in the financial systems of individual countries (especially those with mature market economy) occurred many processes and phenomena influencing shape and functioning of the financial intermediaries. As the most important among them one may consider globalization, deregulation and liberalization, demutualization, privatization, changes in structure and direction of activity conducted by banks or emerging new forms and types of money ${ }^{1}$ [De Nicoló et al., 2003; Hübler, Menkhoff, Suwanaporn, 2008; Kose et al., 2006].

\footnotetext{
1 It must be stressed that dynamics of majority of characterized phenomena would have been significantly lower and the changes they generated significantly smaller without technological progress.
} 
The group of entities especially involved - and at the same time extremely active - into those processes were banks. They have been perceived as the ones who benefited at mentioned tendencies. However, the institutions also encountered problems. Among the most important ones, there was so-called disintermediation ${ }^{2}$. Unlike the phenomena mentioned above, it brought rather negative consequences for banking institutions, as disintermediation erodes competitive position of banks. This, in turn, opens more space for potential rivals, trying to increase their share in the financial market. Due to severe competition, banks, previously entering new areas of financial markets (insurance, securities markets, etc.) have been forced to compete also on their own field. What important, the competition appeared and intensified from the side of the both non-banking "traditional" financial intermediaries and entities labeled as "shadow banking".

Among the first group, one might point at the non-commercial institutions. Such entities, in contrast to operations of shadow banking entities, are not focused solely on incomes, but try to achieve also other goals, often of social character and conducive to local community where the institutions operate. The aim of the paper is to characterize and asses these "positive" non-banking institutions, often omitted - as being of minor importance - in analyses. Among them, of special interest are such alternative, relatively less known, forms of financial activity as credit unions and social lending. With reference to those agents/activities, there are described theoretical background of their functioning, main features, and scale of activity.

\section{Credit unions}

In general, credit unions are financial non-commercial co-operatives owned and controlled by their members. They offer basic financial services and products, with special attention paid to savings and loans. Similarly to cooperative banks, they are rather local in character, ethical and have a good recognition of their clients - their features and financial needs. Members of the credit union can be private persons, connected with professional or organization links and, in particular, the workers employed in one or more enterprises, or persons belonging to the same social or professional organization.

Credit unions are one of the most widespread types of the non-banking financial intermediaries. In 2014 there operated more than 578,000 cooperative owned notfor-profit credit unions in 96 countries, encompassing nearly $217,5 \mathrm{~m}$ of members, having at their balance sheets saving and shares USD 1,470bn and loans USD 1,202bn assets. The global credit union movement holds aggregate assets of more than US\$ $1,79 \mathrm{tn}$ in the retail financial services market. Worldwide, cooperatives financial

2 Disintermediationary tendencies, however, were present in the financial systems worldwide already before the Global Financial Crisis [Heffernan, 2005]. 
institutions of all types serve an estimated ca 900m people [WCCU, 2012, 2015] . $^{3}$ With functioning of such institutions usually are linked numerous advantages for the customers:

- lower operating costs and overheads,

- they enjoy various subsidies and tax exemptions,

- profits returned directly to the members not third party shareholders,

- loan delinquencies lower than banks' (therefore enjoying a further cost saving in the cost of doing business),

- the common bond produces a form of "customer loyalty",

- a friendly and local service.

In theory, credit unions might contribute significantly to ensuring access to affordable (not only in terms of prices but also general conditions of agreements) financial services. Usually, credit unions offer savings, loans and other financial services to clients and the whole communities (like municipalities, small towns, villages, etc.) that otherwise may not have had access due to some geographical, cultural or financial challenges facing individuals, as well as due to their personal features (e.g. relatively low level of economic knowledge). For such groups of clients, credit unions might be the best solution for their problems with arranging and making transactions in the financial market, as the institutions can accomplish goals of this specific clients (who, by the way, are ignored by large banks, as being not enough profitable).

In more detail, the purpose of the credit unions is usually to collect savings (but only from its members), providing them with loans and credits, to carry out on their behalf accounts and to negotiate the conclusion of contracts of insurance. Credit unions offer their members most of the services provided by banks. Clients of credit unions can open their personal accounts with attached payment cards. Credit unions may also maintain accounts of civil partnerships and natural persons conducting business activity. They operate predominantly in the retail customer segment, holding primarily consumer loans in their portfolios (with short maturities).

Thus, credit unions have other than only profit goals - social, financial or even cultural. Moreover, they try to achieve them within a specific supervisory structure that understands and takes into account the nature, risks, and methodologies of credit unions.

All these features proved to be important in the face of the Global Financial Crisis and under conditions which emerged after the crisis. It is said that - unlike other types of financial institutions - credit unions originated only few (if any) subprime

3 The country where credit unions have special significance are the United States. The construction of the credit unions system is also very interesting in the country, as they are chartered by the both federal and state governments. At the end of September, 2012, approximately 2,710 credit unions were chartered by 47 states and Puerto Rico, and approximately 4,320 credit unions were chartered by the federal government. Credit unions had 96 million members, representing more than half of American families, and provided $16.7 \%$ of outstanding consumer credit [Anderson, Liu, 2013]. 
mortgage loans and had not otherwise been the cause of the current economic circumstances. Generally conservative lending policy of these institutions, combined with a specific philosophical mandate to place member needs ahead of institutional profits have restricted credit unions from engaging in careless and risky lending practices. This, in turn, allowed to distinguish them from institutions responsible for making unscrupulous loans before the outburst of the crisis.

Taking this into consideration, one might argue that aside from microeconomic advantages (for the customers) of the credit unions, the institutions generate also macroeconomic benefits, connected with contributing to greater stability of the financial sector and avoiding risky operations and procedures.

\section{Social lending}

As a specific alternative for banks' loans as a source of funds may be perceived also so-called social lending (or person-to-person lending - P2P lending). Plainly, it can be defined as a situation in which individuals are lending money to other individuals without banking intermediation. Thus, a transaction is made directly between the lender and the borrower, with the use of various transaction platforms [Deloitte, 2013; King, 2012]. The pioneer here was ZOPA (Zone of Possible Agreements), operating in the Great Britain.

Peer-to-peer lending (sometimes also called crowdlending) is a direct alternative to a bank loan ${ }^{4}$. It is, however different from loan in that, instead of borrowing from a single source, entities can borrow directly from tens, sometimes hundreds, of individuals who are keen to lend. "Crowdlenders" often bid for loans by offering an interest rate at which they would lend. Borrowers then accept loan offers at the lowest interest rate. Internet-based platforms and techniques are exploited to match lenders with borrowers. Each lender and borrower has own rating connected with track record of previous transactions and reliability. Due diligence is carried out for each loan request, as crowdfunding platforms have a duty to protect both businesses and investor interests. Platforms normally require financial accounts and a trading track record.

At a retail level, there is visible growth in this "crowdfunding" or peer-to-peer services. Apart basic financial transaction P2P may facilitate also more complicated operations. Spurred by growing distrust for conventional banks and provided with support by ever stronger and more ubiquitous online technology, social lending platforms have usurped traditional banking roles in business lines ranging from foreign exchange to raising capital for ventures ${ }^{5}$.

${ }^{4}$ It is important to stress the distinction between peer-to-peer lending and microfinance platforms (like e.g. Kiva). Microfinance typically deals with very small size loans (under $\$ 1,000$ ) and are usually run by non-profit organizations. Such limits are absent in the P2P operations.

5 In Africa, payment services have even leapfrogged the Western countries and introduced ways to pay over a mobile phone that exclude the bank as intermediary altogether. 
Under the label of "social lending" exists many diverse solutions, platforms, and procedures. However, it is possible to identify some common features of this form transferring money from agents with surplus to entities with deficit of funds. Among key features of discussed phenomenon, one might count:

- greater flexibility of interest rates - if any investment project is attractive and popular, investors may compete with each other to lend money to this very business and offer better interest rates to secure the deal,

- possibility of getting a loan even when it was refused by a bank,

- loan sizes can vary significantly so can cater for most needs. The minimum loan size is very small, which encourages a wide range of lenders to participate (banks usually do not engage in small loans, as the calculation of costs is not favorable in such case),

- normally, the loan is repaid through direct debits to the platform, which distributes repayments comfortably out to the lenders,

- activity perceived as positive and even moral for community, as it reinforces mutual relations, activity, and entrepreneurship of citizens,

- disclosure requirements are like that of a bank. Unlike the bank, they are made public to all crowdlenders,

- as with a traditional bank loan, the borrower is legally required to repay the loan.

At first sight, social lending does not constitute any novelty - it involves people with money (investors) lending to people who need money (borrowers). Such transactions have taken place already since the invention of money. However, the transactions - with increasing complexity and scale of economic life - generated costs, which with time turned to be excessive for individuals. This, in turn, contributed to emerging of financial intermediaries - entities able to decrease the transaction costs [Matthews, Thompson, 2014].

Currently, with the explosive growth of the Internet and, in general, IT techniques (and their decreasing costs) and online social network, problems of transaction costs have become relatively less important. New technologies have made costs of direct transactions between surplus and deficit entities significantly lower. Moreover, in the face of free and easy access to the Internet, omnipresent social media and huge computational force provided even by typical computers and software, information advantage of banks over "ordinary" clients have significantly eroded. Obstacles to directly making financial transactions are lesser than anytime earlier in the past. Under current institutional and technological circumstances, borrowers can borrow money from people they have never met, while investors have possibility to lend money to many anonymous borrowers just based on their credit profile [see more: Committee on Global Financial System, 2002).

The scale of social lending is hard to assess, as dozens of companies function enabling this kind of operations all over the world. Among the pioneers was already mentioned ZOPA, starting operations in 2005, in the United States - Prosper 
which began operations in February 2006 (within 9 months it had gathered 100,000 members and funded \$20m in loans) and Lending Club, launched in May 2007 as Facebook application ${ }^{6}$. In subsequent years there were launched also Bobber in Netherland, Smava in Germany, while ZOPA opened its "clones" in Italy and the US7. Interestingly, such platforms have operated also in some emerging countries.

P2P platforms note significant dynamics. For instance, in 2014 the total amount of money loaned by Prosper and Lending Club amounted $\$ 5.98 \mathrm{bn}$, while its dynamics ca $147 \%$ since the beginning of 2014 . As a kind of milestone in the development of social lending may be treated the case of specific support for social lending institutions that occurred in the Great Britain. Namely, in 2012, the government decided about distribution of $£ 55 \mathrm{~m}$ from Business Finance Partnership for SMEs support via social lending platforms.

As it seems, it is the consequence of benefits of social lending for all agents involved. For borrowers impulse to refinancing in that way was the financial crisis. Many of them who had previously found it easy to borrow from banks suddenly realized that they were cut off from this source, as credit crunch occurred worldwide. In the face of crisis vanished also the possibility to use the equity as collateral and thus get loan - value of homes dropped in many countries (especially in the US), as banks became more cautious with kind of transactions. At the same time, resorting to credit card was unavailable to many clients of just too expensive. A specific void emerged in consumer finance. Thus, social lending was treated as a method of filling that gap. Borrowing in this way was not only available for those who - for different reasons - were restricted from bank lending, but it also was clearly cheaper and the procedures connected with getting money - much simpler and faster.

For investors, on the other hand, such operations are highly profitable. Due to lower costs, even with interest rates in P2P transactions lower than banking rates, the rate of return is still very satisfying ${ }^{8}$ Another advantage is the possibility of choosing acceptable level of risk connected with lending through a $\mathrm{P} 2 \mathrm{P}$ platform. It is possible to select low-risk loans where potential borrower has outstanding creditworthiness and the likelihood of default is negligible. But if the lenders prefer higher risk and rate of return, they can as well choose among loans addressed for more risky borrowers. Obviously, the third strategy is available - combination of loans with different characteristics [PWC, 2015].

Very interesting and not quite obvious benefit of social lending is connected with its "social" character itself. Many investors lend through P2P platforms because it is seen as lending to "real" people, investing in specific projects which are well recognized and not anonymous, by contrast with faceless banks or mutual funds.

6 Within a few months Lending Club became a standalone website.

7 In 2008, however, the American ZOPA was closed, due to restrictive policy of the Securities and Exchange Commission.

${ }^{8}$ For instance, some investors in Lending Club and Prosper averaged at last $10 \%$ annualized return, while majority earned more than $6 \%$. 
Additionally, social lending may help in diversification of the portfolio. Such consumer credit is different class of asset in investor's portfolio.

The scale of social lending is hard to assess, as the data on activity of the individual platforms are fragmentary. Nevertheless, even such partial view allows to admit that P2P financial operational are very promising segment. It concerns the US market (where consumers are traditionally more open to innovations), Asia and also Europe.

The European online alternative finance market is strong. Between 2012 and 2014, the 255 platforms of the social lending in 27 European countries (mostly in the UK [65], but also in Germany [31 platforms], France [33], Spain [34], the Netherlands [31], Poland [11] and others) facilitated $€ 4,7 \mathrm{bn}$ worth of funding to European consumers, entrepreneurs, creative artists, SMEs, social enterprises, renewable energy projects, community organizations and good causes. The overall European alternative finance market (including the UK), grew from $€ 487 \mathrm{~m}$ in 2012 to $€ 1,2 \mathrm{bn}$ in 2013 to $€ 2,9 \mathrm{bn}$ in 2014 , with an impressive average yearly growth rate of $146 \%$ [Back, Collins, Zhang, 2014; Wardrop et al., 2015].

The UK takes a lead in P2P solutions, as it is also innovative leader and dominates the European market with some of the most advanced online platforms and sophisticated alternative finance instruments. The UK platforms delivered online $€ 3,56 \mathrm{bn}$ worth of funding to British individuals and small businesses. Besides the UK, the top five European countries in terms of cumulative alternative finance between 2012 and 2014 were: France with $€ 253 \mathrm{~m}$, Germany with $€ 236 \mathrm{~m}$, Sweden with $€ 207 \mathrm{~m}$, the Netherlands with $155 \mathrm{~m}$ and Spain with $€ 101 \mathrm{~m}$. The share of other countries was relatively small - for instance, the Czech Republic and Slovakia noted only $€ 2 \mathrm{~m}$ and $€ 1 \mathrm{~m}$ in 2014 respectively [Wardrop et al., 2015].

The scale development differs when one takes into account peer-to-peer consumer lending, whereby individual borrowers acquire (mostly unsecured) personal loans from a number of other individual lenders (often lending a small amount each) through an online 'marketplace', and peer-to-peer business lending that allows SMEs to obtain growth and working capital directly from a pool of online investors (both individual and institutional), bypassing sometimes prolonged and uncertain bank lending processes.

The first category is the biggest segment in the European alternative finance market when one's excluding the UK. With an average growth rate of $113 \%$ within the years 2012-2014, the European peer-to-peer consumer lending market has developed significantly, from $€ 62.52 \mathrm{~m}$ in 2012 to $€ 157.14 \mathrm{~m}$ in 2013 and $€ 274.62 \mathrm{~m}$ in 2014. The peer-to-peer consumer lending market is particularly strong in France and Germany, both with approximately $€ 80 \mathrm{~m}$ in 2014, as well as in Nordic countries [Back, Collins, Zhang, 2014; PWC, 2015].

On the contrary, the segment of P2P lending to SMEs constitutes relatively new alternative finance model in Europe. Still, it is developing rapidly in a number of key markets. It started with a very low base of $€ 7.79 \mathrm{~m}$ in 2012 but expanded quickly to almost $€ 40 \mathrm{~m}$ in 2013 and $€ 93.1 \mathrm{~m}$ in 2014 . Its average growth rate of $272 \%$ is the 
highest among major alternative financing models. For many SMEs, the speed with which they are able to obtain business loans, the often more flexible and attractive terms of financing (e.g. no penalty for early repayments) makes this comfortable and fast method of getting loans. Important is also here transparency of making transaction, especially with comparison to long and complex banks' procedures.

The described advantages of social lending make it very promising alternative for commercial banks. Of course, also P2P transactions have some disadvantages and may generate problems ${ }^{9}$ (problems for the older clients, building connections between financial and technological exclusion, scope and scale of necessary regulations, etc.). Still, the first ten years of social lending may be seen as positive. The open question remains, whether banks decide to compete with the P2P platforms or rather to collaborate with them or even include them into exiting business models.

\section{Conclusions}

Disintermediation has significantly changed competitive position and role of the commercial banks within the financial systems. It is worth stressing that, among other factors, important role in this decline of banking played the Global Financial Crisis, contributing to growing distrust in financial institutions in general and in banks particularly. The customers, in part, forced to this by credit crunch and tightening of bank' policies and procedures, and in part just taken a dislike, decided to limit their relations with banks. Still, both the households and small entrepreneurs needed to fulfill their financial needs and a natural choice as to turn to other institutions.

Under such conditions there emerged room for development of alternatives for commercial banking. Some of them were already well known, like the cooperative banks or credit unions, while the other - started to operate just in the last decade, like the social lending platforms. Their common future is more social character, as they function and operate closer to the clients, and their offer is more convenient and transparent than the one in the large commercial banks.

What is characteristic, these alternative institutions managed relatively well with the Global Financial Crisis and its consequences. Obviously, there occurred a drop in their main activities, but these negative tendencies in most cases were overcome. Moreover, the credit unions and the P2P platforms increased the number of their client, as they were perceived as less risky and more available for common clients. Such conclusion may be drawn with reference for most countries, though there was, of course, significant regional dispersion. The development of those alternatives was not restricted only to the countries with mature financial systems - similar tendencies were visible also in such countries as Poland or the Czech Republic.

9 As an example, one may consider huge $(\$ 7,6 \mathrm{bn})$ fraud connected with operations of the Chinese social lending portal Ezubao, revealed in February of 2016. 
In general, one may argue that characterized institution has many advantages. Moreover, they are institutions which may be treated as limiting problems connected with financialization. Still, at the moment it is, of course, hard to believe that these institutions may - and should - compete with commercial banks. They have rather complementary character. Nevertheless, analysis of their features, organization, goals and business models may give insight into building a stable, sound and just financial system.

\section{Bibliography}

Anderson R.G., Liu Y., Banks and credit unions. Competition is not going away, "The Regional Economist" 2013, April.

Back P., Collins L., Zhang B., Understanding alternative finance. The UK Alternative Finance Industry. Report 2014, University of Cambridge, November 2014.

Committee on Global Financial System, IT innovations and financial patterns: Implications for the financial systems, BIS, Basel, February 2002.

De Nicoló G., Bartholomew P., Zaman J., Zephirin M., Bank Consolidation, Conglomeration and Internationalization: Trends and Implications for Financial Risk, "IMF Working Paper" 2003, No. 158.

Deloitte, Banking disrupted. How technology is threatening the traditional European retail banking model, 2013.

Heffernan S., Modern Banking, John Wiley \& Sons, Chichester 2005.

Hübler O., Menkhoff L., Suwanaporn C., Financial Liberalisation in Emerging Markets: How Does Bank Lending Change?, "The World Economy" 2008, No. 31.

King B., Banking 3.0., Wiley, New York 2012.

Kose M.A., Prasad E., Rogoff K., Wei S.J., Financial Globalization: A Reappraisal, "IMF Working Paper" 2006, No. 189.

Matthews K., Thompson J., The Economics of Banking, Wiley, Oxford 2014.

PWC, Peer pressure. How peer-to-peer lending platforms are transforming the consumer lending industry, Price Waterhouse Coopers, February 2015.

Wardrop R., Zhang B., Rau R., Gray M., Moving Mainstream. The European Alternative Finance Benchmarking Report, University of Cambridge-EY, February 2015.

WCCU, Credit Unions Worldwide. 2011-1995. Historical Data, Washington 2012.

WCCU, Credit Unions Worldwide. 2014 Statistical Report, Washington 2015.

\section{Niekomercyjne instytucje pośrednictwa finansowego jako alternatywa dla banków komerycjnych w gospodarce po kryzysie finansowym}

Celem artykułu jest charakterystyka i ocena alternatywnych (niekomercyjnych) form działalności finansowej: unii kredytowych i pożyczek społecznych jako alternatywy dla banków komercyjnych. Instytucje te nie koncentrują się wyłącznie na zyskach, ale starają się osiągnąć inne cele, często o charakterze społecznym, mogące sprzyjać społeczności lokalnej. W tym kontekście opisano syntetycznie teoretyczne podstawy ich funkcjonowania, ich typy, skalę aktywności w krajach UE oraz główne cechy tych podmiotów, a także zalety i wady niebankowych pośredników finansowych. 
Pobrane z czasopisma Annales H - Oeconomia http://oeconomia.annales.umcs.pl

Data: 26/04/2023 16:33:49

\section{Non-commercial Financial Intermediaries as an Alternative for Commercial Banks in the Post-crisis Economy}

The aim of the paper is to characterize and asses alternative (non-commercial) forms of financial activity: credit unions and social lending. Such institutions, in contrast to banking entities, are not focused solely on incomes, but try to achieve also other goals, often of social character and those which may be conducive to local community where the institutions operate. With reference to those agents/activities, there are described theoretical background of their functioning, their types, scale of activity in the EU countries and main features of those entities along with advantages and disadvantages of non-commercial financial intermediaries. 